\title{
Analisis Pengaruh Perubahan Beban Generator Terhadap Efsiensi Kinerja PLTU Bosowa Energi Jeneponto Unit 2
}

\author{
Andreas Pangkung ${ }^{*}$, Herman Nawir $^{2}$ dan Aditya Nugraha Adji Santoso ${ }^{3}$ \\ 1,2,3 Jurusan Teknik Mesin, Politeknik Negeri Ujung Pandang, Makassar 90245, Indonesia \\ *andareas_pangkung@poliupg.ac.id
}

\begin{abstract}
This study aims to determine the effect of changes in generator load on efficiency performance in steam power plants and to determine the amount of input power in the boiler. Data collection was carried out at PT. Bosowa Energi PLTU Jeneponto. The data are the power output, fuel consumption, and the calorific value of the fuel. Then perform data analysis by calculating input power and efficiency. From the result of the study, the highest efficiency is on May 20, 2018 at 18.00 with a load of $90.00 \mathrm{MW}$, namely 55.68\% and the lowest efficiency is on May 12, 2018 at 03.00 with a load of $64.98 \mathrm{MW}$, namely 22.69\%. The highest boiler input power based on the analysis results was on May 3, 2018 at 20.00, namely 356.61 MW, and the lowest boiler input power based on the analysis was on May 15, 2018 at 07.00, namely 128.14 MW.
\end{abstract}

Keywords: Efficientcy; Input Power; Output Power; Steam Power Plant.

\begin{abstract}
Abstrak: Penelitian ini bertujuan untuk mengetahui pengaruh perubahan beban generator terhadap efisiensi kinerja pada pembangkit listrik tenaga uap dan mengetahui jumlah daya masukan pada boiler. Pengambilan data dilakukan di PT. Bosowa Energi PLTU Jeneponto. Data tersebut yaitu daya output, konsumsi bahan bakar dan nilai kalor bahan bakar. Kemudian melakukan analisa data dengan menghitung daya input dan efisiensi. Hasil penelitian ini yaitu efisiensi tertinggi terdapat pada tanggal 20 Mei 2018 pada pukul 18.00 dengan beban 90,00 MW yaitu 55,68\% dan efisiensi terendah terdapat pada tanggal 12 Mei 2018 pada pukul 03.00 dengan beban 64,98 MW yaitu 22,69 \% . Daya input boiler tertinggi berdasarkan hasil analisa terdapat pada tanggal 3 Mei 2018 pada pukul 20.00 yaitu 356,61 MW, serta daya input boiler terendah berdasarkan hasil analisa terdapat pada tanggal 15 Mei 2018 pada pukul 07.00 yaitu 128,14 MW.
\end{abstract}

Kata kunci : Efisiensi; Daya Input; Daya Output; PLTU.

\section{PENDAHULUAN}

Pembangkit Listrik Tenaga Uap (PLTU) pada umumnya merupakan unit pembangkit yang terbesar dalam sistem karena secara teknis ukuran kapasitasnya juga yang paling besar. Hal ini menyebabkan bahwa dalam mengoperasikan sistem tenaga listrik kendala operasi yang dihadapi PLTU perlu mendapat perhatian khusus. Secara teknis kebetulan juga PLTU paling banyak kendala operasinya, hal ini disebabkan karena proses konversi energi yang terjadi di PLTU cukup panjang dan tiap bagian pada jalur proses perubahan energi ini, tidak sama kemampuannya untuk menghadapi perubahan beban.

Pembangkit listrik tenaga uap merupakan suatu sistem pembangkit tenaga yang fluidanya diuapkan dan dikondensasikan secara berulang-ulang dalam sebuah siklus tertutup, misalnya pada PLTU Bosowa Energi Jeneponto. Dalam kegiatannya PLTU Bosowa Energi Jeneponto membutuhkan tenaga listrik sebesar 2 x $125 \mathrm{MW}$.

Mengingat proses konversi energi yang panjang pada PLTU, maka kemampuan sebuah PLTU untuk menghadapi perubahan beban dalam sistem sangat tergantung kepada besarnya tempat penyimpanan energi misalnya ruang bakarnya dan drum ketelnya. Lambatnya kemampuan sebuah PLTU untuk menghadapi perubahan beban akan menyebabkan pemborosan bahan bakar sehingga akan berpengaruh terhadap efisiensi PLTU. 
Energi berupa panas dikonversikan menjadi energi mekanikal yang menggerakkan sebuah generator, perubahan energi panas menjadi mekanikal dan energi listrik ini melalui suatu siklus konversi energi yang sangat bergantung pada jumlah panas, pola suhu dan suhu lingkungan atau suhu penerima panas yang tersedia, dalam hal ini boiler. Suatu siklus panas menerima sejumlah energi panas pada suatu suhu tertentu, dan merubah sebagian energi panas itu menjadi kerja, membuang atau meneruskan yang selebihnya kepada lingkungan atau penerima panas itu sebagai "energi kerugian" pada suhu yang lebih rendah, dalam hal ini dapat dilihat pada fungsi kondensor.

Siklus Rankine atau siklus tenaga uap merupakan siklus teoritis paling sederhana yang mempergunakan uap sebagai media kerja sebagaimana dipergunakan pada sebuah pusat listrik tenaga uap. Pusat listrik tenaga uap yang terdiri atas komponen-komponen terpenting yaitu : Boiler, Turbin Uap, Kondensor dan Generator listrik. Jumlah energi masuk sebagai bahan bakar melalui boiler adalah $E_{m}$, sedangkan energi efektif yang tersedia pada poros turbin adalah energi kerja $E_{k}$. Energi yang terbuang melalui kondensor adalah sebesar $E_{b}$. Dengan menganggap semua kerugian lainya adalah $\mathrm{E}_{\mathrm{b}}$.

Adapun komponen Utama pada PLTU yaitu sebagai berikut:

\section{Boiler}

Boiler adalah salah satu peralatan utama suatu PLTU yang berfungsi untuk mengubah air menjadi uap dengan memanfaatkan energi panas yang diperoleh dari hasil pembakaran bahan bakar seperti batu bara, HSD (High Speed Diesel), Gas, MFO (Marine Fuel Oil), ada beberapa jenis boiler:

\subsection{Boiler Stoker Mekanik}

Jenis boiler ini menggunakan rantai berjalan sebagai tempat pembakaran terjadi. Udara panas ditiupkan dari bawah rantai sehingga batu bara terbakar. Boiler jenis ini dapat membakar berbagai jenis batu bara, limbah kayu, kulit kayu, bahkan sampah anorganik.

\subsection{Boiler Pulverized}

Jenis boiler ini yang paling banyak digunakan pada saat ini, menggunakan mill untuk menggiling batu bara menjadi serbuk sebelum diumpankan ke ruang bakar.

\subsection{Boiler CFB (Circulating Fluidized Bed)}

Prinsip kerjanya hampir sama dengan boiler stoker mekanik, tidak menggunakan rantai, udara dengan tekanan dan kecepatan tinggi dihembuskan dari dasar furnace sehingga batu bara melayang dan terbakar.

\section{Turbin Uap}

Turbin uap adalah pesawat dengan aliran tetap (steady-flow) machine. Turbin uap mendapat energi uap yang bertemperatur dan bertekanan tinggi yang berekspansi melalui sudu-sudu turbin, dimana uap melalui nozzel di ekspansikan ke sudu-sudu turbin dengan penurunan tekanan yang drastis sehingga terjadi perubahan energi kinetik pada uap. Energi kinetik uap yang keluar dari nozzel diberikan pada sudu-sudu turbin. Akibatnya, poros turbin berputar dan menghasilkan tenaga.

\section{Kondensor}

Kondensor merupakan peralatan untuk mengembunkan kembali uap yang telah dimanfaatkan untuk memutar turbin uap. Hal ini diperlukan untuk menghemat sumber air yng ada di sekitarnya serta menjamin kemurnian air yang digunakan dalam sistem turbin uap agar tidak terjadi pengendapan maupun kotoran-kotoran yang dapat merusak. Sebagai pendingin kondensor biasanya menggunakan air dingin seperti air sungai, laut atau air tanah yang sudah diproses melalui water treatment terlebih dahulu. 


\section{Generator}

Generator AC (Alternating Current) yang akan dibahas adalah generator yang termasuk jenis mesin serempak (mesin sinkron) dimana frekuensi listrik yang dihasilkan sebanding dengan jumlah kutup dan putaran yang dimilikinya. Listrik yang dihasilkan adalah listrik arus bolak balik (listrik AC). Mesin penggeraknya dapat berasal dari tenaga air, tenaga uap, mesin diesel, dan sebagainya. Generator AC banyak kita jumpai pada pusat-pusat listrik (dengan kapasitas yang relatif besar).

Disini umumnya generator AC disebut dengan alternator atau generator saja. Selain generator $\mathrm{AC}$ dengan kapasitas yang relatif besar tersebut, kita mengenal pula generator dengan kapasitas yang relatif kecil. Misalnya generator yang dipakai untuk penerangan darurat dan untuk penerangan daerah-daerah terpencil. Generator tersebut sering disebut home light atau generator set.

Dibandingkan dengan generator DC (Direct Current), generator AC lebih cocok untuk pembangkit tenaga listrik berkapasitas besar. Hal ini didasarkan atas pertimbangan- pertimbangan, antara lain:

\section{Timbulnya masalah komutasi pada generator DC}

2. Timbulnya persoalan dalam hal menaikkan atau menurunkan tegangan pada listrik DC. Hal ini menimbulkan persoalan untuk hantaran dalam pengiriman tenaga listrik (transmisi atau distribusi), masalah penampang kawat, tiang transmisi dan rugi- rugi.

3. Listrik AC relatif lebih mudah untuk diubah menjadi listrik DC.

4. Masalah efisiensi mesin dan lain-lain pertimbangan.

Konstruksi generator AC lebih sederhana dibandingkan generator DC. Bagian-bagian terpenting dari generator $\mathrm{AC}$ adalah :

1. Rangka Stator, dibuat dari besi tuang. Rangka stator merupakan rumah dari bagian-bagian generator yang lain.

2. Stator, bagian ini tersusun dari plat-plat (seperti yang digunakan juga pada jangkar dari mesinmesin arus searah) stator yang mempunyai alur-alur sebagai tempat meletakkan lilitan stator. Lilitan stator berfungsi sebagai tempat terjadinya GGL (Gaya Gerak Listrik) induksi.

3. Rotor, rotor merupakan bagian yang berputar. Pada rotor terdapat kutub- kutub magnet dengan lillitannya yang dialiri arus searah, melewati cincin geser dan sikat-sikat.

4. Slip Ring atau Cincin Geser, dibuat dari bahan kuningan atau tembaga yang dipasang pada poros dengan memakai bahan isolasi. Slip ring ini berputar bersama-sama dengan poros rotor. Jumlah slip ring ada dua buah yang masing-masing slip ring dapat menggeser sikat arang yang masingmasing merupakan sikat positif dan sikat negatif, berguna untuk mengalirkan arus penguat magnet ke lilitan magnet pada rotor.

5. Generator Penguat, generator penguat adalah suatu generator arus searah yang dipakai sebagai sumber arus. Biasanya yang dipakai adalah dinamo shunt. Generator arus searah ini biasanya dikopel terhadap mesin pemutarnya bersama generator utama. Akan tetapi sekarang banyak generator yang tidak menggunakan generator arus searah (dari luar) sebagai sumber penguat, sumber penguat diambil dari GGL sebagian kecil belitan statornya. GGL tersebut ditransformasikan kemudian disearahkan dengan penyearah elektronik sebelum masuk pada bagian penguat.

Adapun prinsip kerja dari generator sinkron secara umum adalah sebagai berikut :

1. Kumparan medan yang terdapat pada rotor dihubungkan dengan sumber eksitasi tertentu yang akan mensuplai arus searah terhadap kumparan medan. Dengan adanya arus searah yang mengalir 
melalui kumparan medan maka akan menimbulkan fluks yang besarnya terhadap waktu adalah tetap.

2. Penggerak mula yang sudah terkopel dengan rotor segera di operasikan sehingga rotor akan berputar pada kecepatan nominalnya.

3. Perputaran rotor tersebut sekaligus akan memutar medan magnet yang dihasilkan oleh kumparan medan. Medan putar yang dihasilkan pada rotor, akan diinduksikan pada kumparan jangkar sehingga pada kumparan jangkar yang terletak di stator akan dihasilkan fluks magnetik yang berubah-ubah besarnya terhadap waktu. Adanya perubahan fluks magnetik yang melingkupi suatu kumparan akan menimbulkan ggl induksi pada ujung-ujung kumparan tersebut

Untuk mengalirkan arus penguat ke lilitan penguat yang berputar tetap diperlukan cincin geser dan sikat arang. Meskipun demikian bukan berarti bahwa hal tersebut memberatkan karena arus penguat magnet tidak begitu besar dan tegangannya pun rendah.

Bagian-bagian terpenting dari stator adalah rumah stator, inti stator dan lilitan stator. Inti stator adalah sebuah silinder yang berlubang, terbuat dari plat-plat dengan alur-alur di bagian kelilling dalamnya. Didalam alur-alur itu dipasang lilitan statornya. Ujung-ujung lilitan stator ini dihubungkan dengan jepitan-jepitan penghubung tetap dari mesin. Bagian-bagian terpenting dari rotor adalah kutup-kutup, lilitan penguat, cincin geser dan sumbu. Konstruksi generator yang umum digunakan adalah jenis kutub dalam dan yang selanjutnya dibicarakan adalah konstruksi generator kutub dalam ini. Kelebihan generator kutub dalam pada intinya adalah bahwa genrator ini dapat menghasilkan tenaga listrik yang sebesar-besarnya, karena tegangan yang terbentuk dapat langsung diambil dari lilitan statornya.

Secara umum kutub magnet mesin sinkron dibedakan atas :

1. Kutub magnet dengan bagian kutub yang menonjol (salient pole). Konstruksi seperti ini digunakan untuk putaran rendah, dengan jumlah kutub yang banyak.

2. Kutub magnet dengan bagian kutub yang tidak menonjol (non salient pole). Konstruksi seperti ini digunakan untuk putaran tinggi, dengan jumlah kutub yang sedikit. Kira-kira 2/3 dari seluruh permukaan rotor dibuat alur-alur untuk tempat lilitan penguat. Yang 1/3 bagian lagi merupakan bagian yang utuh, yang berfungsi sebagai inti kutub ialah :

Menurut teori listrik, GGL induksi yang dihubungkan pada kumparan dalam medan magnet

$$
\begin{aligned}
& E=4.44 . f . \phi . N(\text { Volt }) . \\
& E=2.22 . f . \phi . Z \text { (Volt)... }
\end{aligned}
$$

dengan:

E : GGL induksi (Volt)

f : Frekuensi listrik (Hz)

Z : jumlah sisi lilitan

$$
f=\frac{P \cdot n}{120}
$$

$\mathrm{N} \quad$ : jumlah lilitan

$\phi \quad$ : besarnya fluks magnet (Weber)

dengan:

f $\quad$ : frekuensi listrik

$\mathrm{n} \quad$ : putaran generator per menit

P : banyaknya kutub magnet

Jadi jika nilai f dimasukkan ke persaman diatas maka : 
245 Andreas Pangkung, Herman Nawir, Aditya Nugraha Adji Santoso. Analisis Pengaruh Perubahan Beban Generator Terhadap Efsiensi Kinerja PLTU Bosowa Energi Jeneponto Unit 2

$$
\mathrm{E}=4.44 \cdot \frac{P \cdot n}{120} \cdot \phi \cdot \mathrm{N}
$$

Karena nilai $\mathrm{P}$ dan $\mathrm{N}$ tidak berubah pada generator maka harga-harga yang tidak berubah akan dijadikan menjadi suatu ketetapan yang kita sebut dengan Konstanta (K) sehingga persamaan lebih mudah untuk dipahami.

$$
\mathrm{E}=\mathrm{K} \cdot \mathrm{n} \cdot \phi
$$

dengan:

$$
\begin{aligned}
& \text { E : GGL induksi (Volt) K : konstanta } \\
& \text { ф : besarnya fluks magnet (Weber) }
\end{aligned}
$$

Banyak penyediaan listrik terdiri atas sistem tiga fase, dan terdapat tiga pasangan elektromagnet yang terpisah serta tiga set kumparan yang juga terpisah. Antara masing-masing fase terdapat selisih 120 derajat listrik antara arus ketiga fase. Ketiga fase itu biasanya ditandai $\mathrm{u}-\mathrm{v}-\mathrm{w}$, atau juga r-s-t, dan dapat menurut hubungan delta atau hubungan bintang. Tegangan antara dua fase adalah V. Khusus pada hubungan bintang, terdapat titik bintang, yang diberi tanda 0. Tegangan antara fase dan titik bintang adalah $\mathrm{V} / \sqrt{3}$. Daya sebuah generator 3 phasa dinyatakan dalam rumus berikut :

$$
\mathrm{P}=\sqrt{3} \mathrm{~V}_{\mathrm{L}-\mathrm{L}} . \mathrm{I} . \operatorname{Cos} \phi
$$

atau

$\mathrm{P}=3 \mathrm{~V}_{\mathrm{L}-\mathrm{N}} . \mathrm{I}$. Cos $\phi(\mathrm{V}$ dalam satu phasa $)$

dengan:

$\mathrm{P} \quad$ : daya $(\mathrm{W})$

$\mathrm{V}_{\mathrm{L}-\mathrm{L}}$ : tegangan phasa-phasa $(\mathrm{V})$

$\mathrm{V}_{\mathrm{L}-\mathrm{N}}$ : tegangan phasa-netral $(\mathrm{V})$

I : arus beban (A)

$\operatorname{Cos} \varphi$ : faktor daya

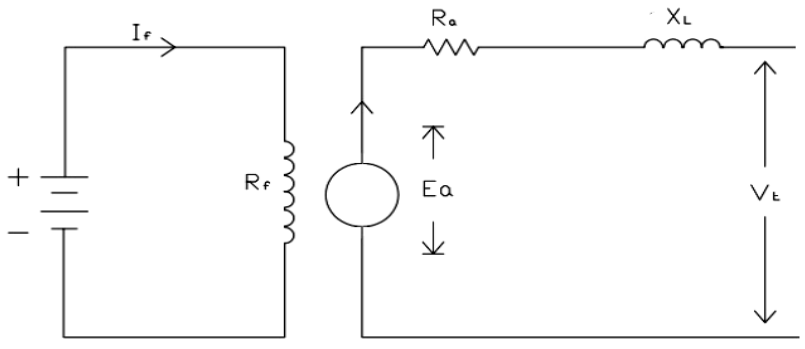

Gambar 1. Rangkaian listrik generator tanpa beban (Sumanto, 1996)

\section{Keteraangan :}

$\mathrm{I}_{\mathrm{f}}$ : arus kumparan medan atau arus penguat

$\mathrm{X}_{\mathrm{L}}$ : reaktansi bocor

$\mathrm{R}_{\mathrm{f}}$ : hambatan kumparan medan

$\mathrm{V}_{\mathrm{t}}$ : tegangan output/terminal

$\mathrm{R}_{\mathrm{a}}$ : hambatan jangkar

$\mathrm{E}_{\mathrm{a}}$ : gaya gerak listrik jangkar

Pada generator sinkron keadaan jalan tanpa beban mengandung arti bahwa arus jangkar $(\mathrm{Ia})=0$. Dengan demikian besar tegangan terminal adalah :

$$
\mathrm{Vt}=\mathrm{Ea}=\mathrm{Eo}
$$




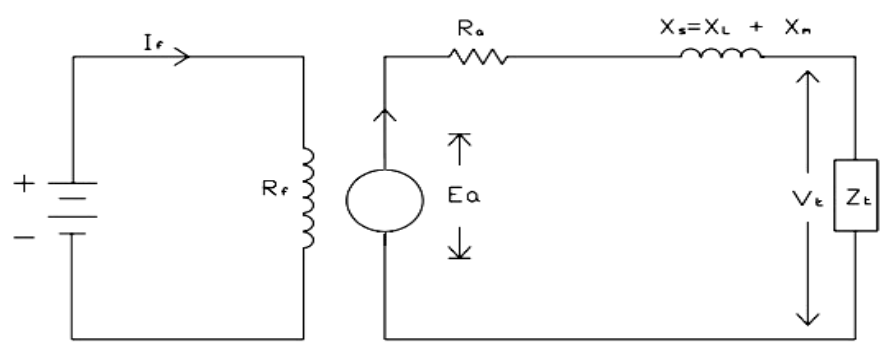

Gambar 2. Rangkaian listrik generator berbeban (Sumanto, 1996)

Pada generator sinkron berbeban, maka pada kumparan armatur timbul Ia dan Xm akibatnya timbul penurunan GGL jangkar tanpa beban. Tegangan terminal Vt yang timbul adalah :

$$
\begin{aligned}
\mathrm{Vt} & =\mathrm{Ea}-\mathrm{I}(\mathrm{Ra}+\mathrm{j} \mathrm{Xs}) . \\
\mathrm{Vt} & =\mathrm{Ea}-\mathrm{Ia} \mathrm{Zs}
\end{aligned}
$$

Efisiensi PLTU banyak dipengaruhi ukuran PLTU, karena ukuran PLTU menentukan ekonomis tidaknya penggunaan pemanas ulang dan pemanas awal. Efisiensi pada boiler diberikan dengan persamaan sebagai berikut:

$$
\begin{aligned}
& \text { Efisiensi Boiler }(\eta)=\frac{\text { Panas Kelwar }}{\text { Panas Masuk }} \times 100 \% \\
& \text { Efisiensi Boiler }(\eta)=\frac{Q \cdot\left(h_{g}-h_{f}\right)}{q \cdot G C V} \times 100 \% \ldots
\end{aligned}
$$

Parameter yang dipantau untuk perhitungan efisiensi boiler adalah:

1. Jumlah steam yang dihasilkan per jam (Q) dalam $\mathrm{kg} / \mathrm{jam}$

2. Jumlah bahan bakar yang dipergunakan per jam (q) dalam $\mathrm{kg} / \mathrm{jam}$

3. Tekanan kerja $\left(\mathrm{kg} / \mathrm{cm}^{2}\right)$ dan suhu lewat panas $\left({ }^{\circ} \mathrm{C}\right)$, jika ada

4. Suhu air umpan $\left({ }^{\circ} \mathrm{C}\right)$

5. Jenis bahan bakar dan nilai kotor bahan bakar (GCV) dalam kkal/kg bahan bakar

6. Entalpi steam jenuh dalam $\mathrm{kkal} / \mathrm{kg}$ steam (hf)

7. Entalpi air umpan dalam kkal/kg air (hg)

Efisiensi perubahan energi pada turbin uap sampai kepada tenaga mekanis di kopling turbin didapat dari :

$$
\eta_{t t}=\frac{h_{1}-h_{2}}{h_{1}}=\frac{\text { panas yang terpakai }}{\text { panas yang masuk }}
$$

Efisiensi generator dapat dihitung dengan persamaan berikut:

$$
\eta=\frac{P_{\text {out }}}{P_{\text {out }}+P_{\text {rugi-rugi }}}
$$

dengan:

Pout $=$ daya yang dikeluarkan $=$ Vt. IL $($ Watt $)$

Pin $=$ daya yang dimasukkan $=$ Pout + Prugi-rugi

Prugi-rugi $=$ rugi-rugi mekanik + histerisi + inti dll

Jadi efisiensi keseluruhan pada PLTU mulai dari bahan bakar sampai pada energi listrik yang dihasilkan dapat dihitung dengan persamaan berikut:

$$
\eta=\frac{P_{\text {out }}}{P_{\text {in }}} \times 100 \%
$$


247 Andreas Pangkung, Herman Nawir, Aditya Nugraha Adji Santoso. Analisis Pengaruh Perubahan Beban Generator Terhadap Efsiensi Kinerja PLTU Bosowa Energi Jeneponto Unit 2

dengan:

$\mathrm{P}_{\text {out }}=$ energi keluaran pada generator $($ Watt $)$

$P_{\text {in }}=$ energi masukan pada boiler/ketel uap (Watt)

Untuk mendapatkan $P_{\text {in }}$ keseluruhan PLTU dapat digunakan persamaan berikut :

$\mathrm{P}_{\text {in }}=$ konsumsi bahan bakar $\times$ nilai kalor bahan bakar

dengan:

Konsumsi bahan bakar dalam kg/jam

Nilai kalor bahan bakar dalam $\mathrm{kkal} / \mathrm{kg}$

Penelitian kinerja PLTU telah banyak dilakukan, telah dilakukan penelitian dengan menganalisa pola produksi steam pada boiler di PLTU, diperoleh daya maksimum dalam seminggu sebesar 241,424 MW dengan kapasitas energi kalor sebesar 278,576 MW [1].

Penelitian lainnya adalah analisis variasi beban yang berubah-ubah, yang dilakukan di PT Indonesia power unit pembangkit Semarang diperoleh efisiensi generator sebesar 93,963-94,033\% [2], juga dilakukan di PLTU Cilacap unit 1 dan 2 diperoleh efisiensi sebesar 92,17-99,88 \% [3], juga dilakukan di PLTU Tanjung Awar-Awar dengan variasi beban 75\%, 85\% dan 100\% diperoleh efisiensi turbin dengan beban secara berurut $75 \%, 85 \%$ dan $100 \%$ efisiensinya adalah $86,02 \%, 87,2 \%$ dan $88,64 \%$ [4].

Penelitian lainnya adalah dengan melakukan analisis kinerja generator di PT PJB UBJOM PLTU rembang unit 10 dan 20 diperoleh efisiensi rata-rata sebesar 92,39\% [5], juga dilakukan penelitian analisis efisiensi termal boiler di PLTU Amurang unit 1 diperoleh efisiensi 91,73-92,33\% [6].

Penelitian lainnya adalah dengan melakukan analisis kehilangan panas, penelitian ini dilakukan di PLTU Asam-Asam Kalimantan Selatan diperoleh efisiensi boiler 82,12 - 86,23\% [7], penelitian ini juga dilakukan di PLTU unit 1 PT Semen Tonasa diperoleh efisiensi sebesar 84,96\% [8].

Penelitian dengan motode input-output dilakukan di PLTU Banten unit 2 diperoleh efisiensi $83,4 \%$ [9], sedangkan penelitian dengan metode langsung dan tak langsung dilakukan di PLTU 2 unit 2 Banten-Labuang diperoleh efisiensi dengan metode langsung sebesar 87,3\% dan metode tak langsung sebesar $85,03 \%$ [10].

\section{METODE PENELITIAN}

Penelitian ini dilakukan dengan cara metode observasi dengan mengadakan pengamatan langsung terhadap proses pengoperasian dan sistem yang ada pada PLTU Bosowa Energi Jeneponto, melakukan pengambilan data daya output generator, konsumsi bahan bakar dan nilai kalor bahan bakar dengan cara melakukan wawancara atau diskusi dengan narasumber dari perusahaan yang memiliki pengetahuan mengenai pengoperasian dan sistem. 


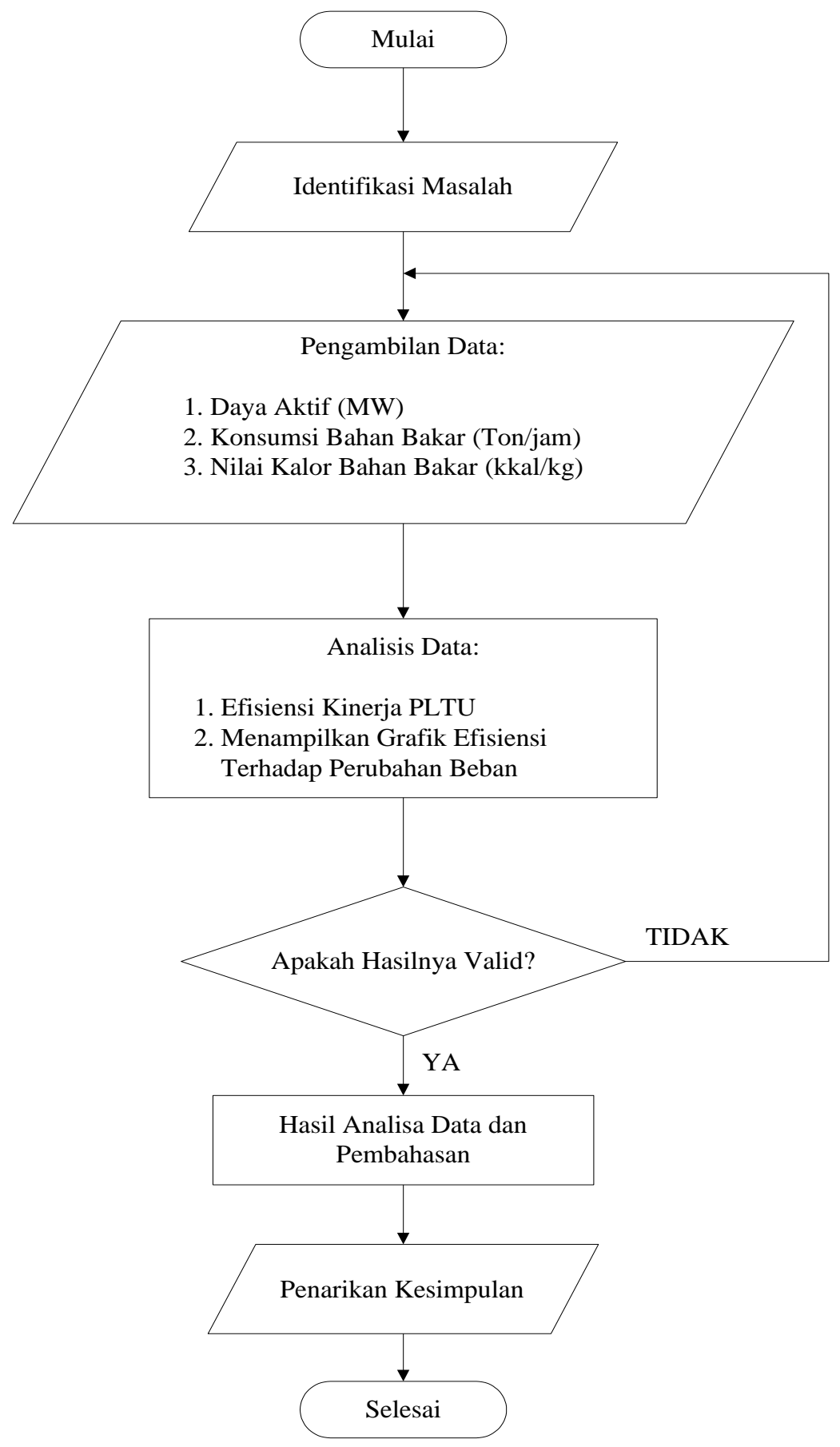

Gambar 3. Diagram Alir Penelitian

\section{HASIL DAN PEMBAHASAN}

Berdasarkan dari hasil analisa, maka grafik hubungan antara Efisiensi PLTU terhadap beban listrik dapat dilihat pada gambar dibawah ini: 
249 Andreas Pangkung, Herman Nawir, Aditya Nugraha Adji Santoso. Analisis Pengaruh Perubahan Beban Generator Terhadap Efsiensi Kinerja PLTU Bosowa Energi Jeneponto Unit 2

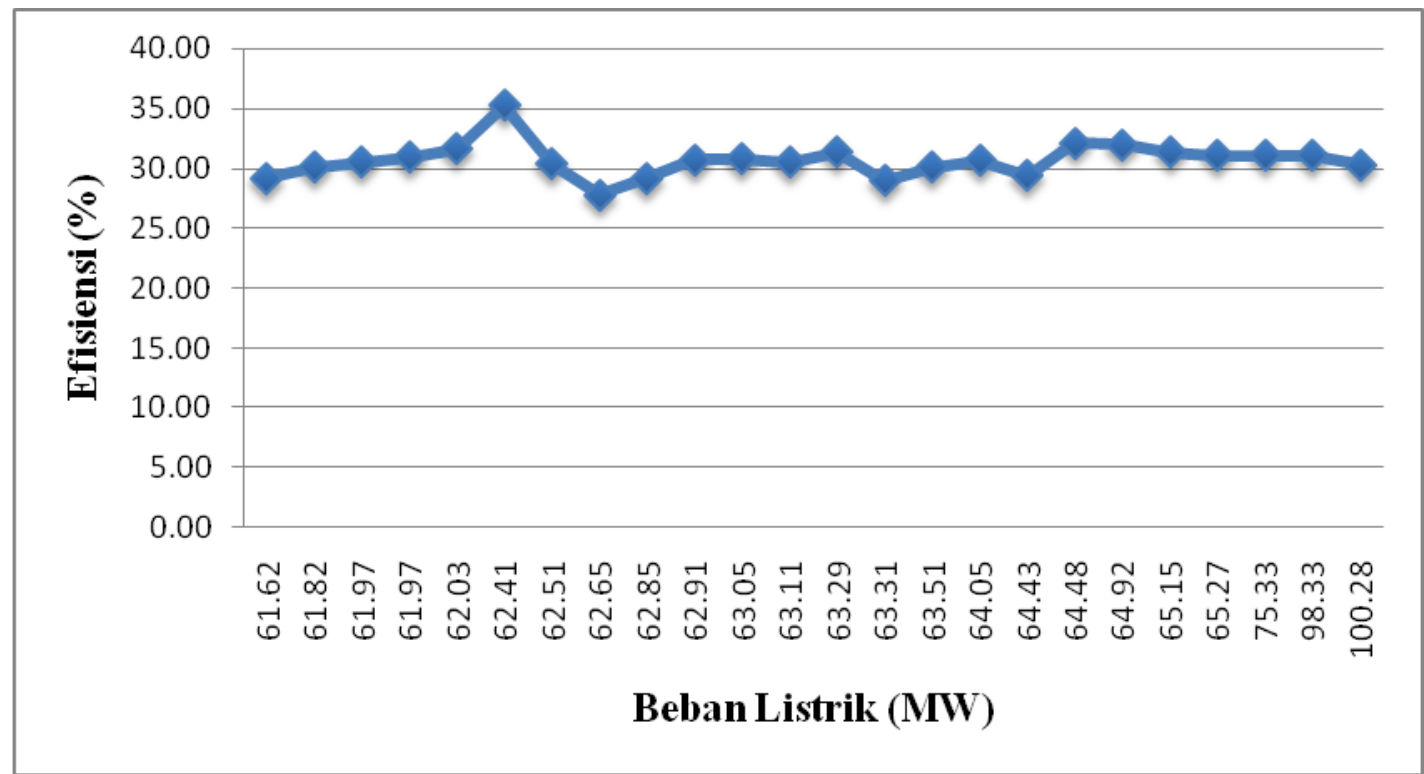

Gambar 4. Hubungan antara Efisiensi PLTU Terhadap Beban Listrik (16 Mei 2018)

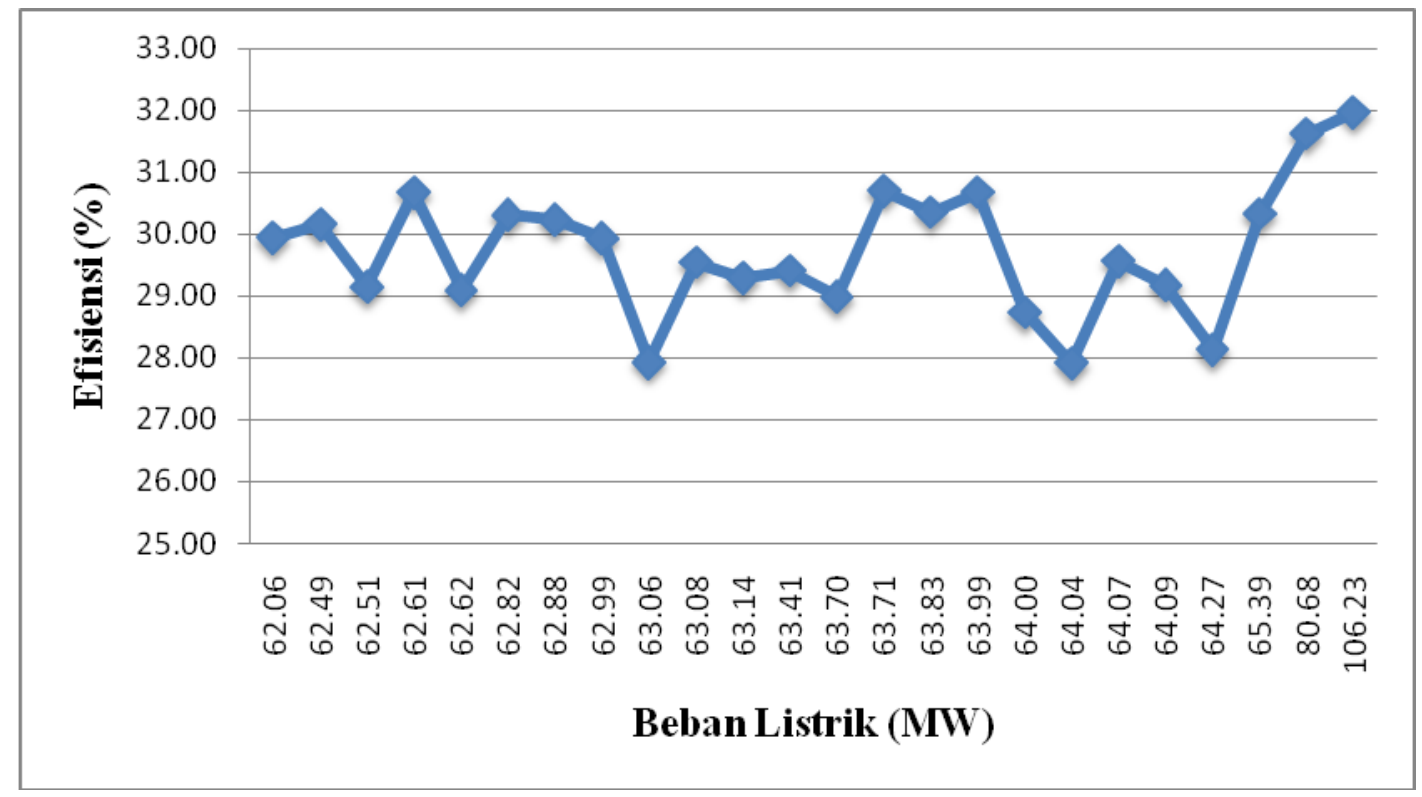

Gambar 5. Hubungan antara Efisiensi PLTU Terhadap Beban Listrik (17 Mei 2018)

Berdasarkan gambar 4 grafik hubungan antara efisiensi terhadap beban listrik mengalami perubahan fluktuatif. Terlihat nilai efisiensi mengalami kenaikan hingga beban 62,51 MW, namun pada beban 62,51 MW, 63,31 MW dan 64,43 MW mengalami penurunan efisiensi diakibatkan karena beda banyaknya jumlah konsumsi bahan bakar yang dibutuhkan untuk menghasilkan daya. Dimana efisiensi turbin yang paling tinggi diperoleh pada kondisi beban 62,41 MW yaitu 35,26\% sedangkan efisiensi terendah diperoleh pada kondisi beban $62,65 \%$ yaitu $27,80 \%$.

Berdasarkan gambar 5 hubungan antara efisiensi terhadap beban listrik mengalami perubahan fluktuatif. Dimana dilihat pada beban 63,06 MW, 64,04 MW dan 64,27 MW mengalami penurunan yang signifikan diakibatkan karena beda banyaknya jumlah konsumsi bahan bakar yang dibutuhkan 
untuk menghasilkan daya. Namun terlihat nilai beban mengalami kenaikan terlihat dari beban $65,35 \%$ hingga beban 106,23. Dimana efisiensi turbin yang paling tinggi diperoleh pada kondisi beban 106,23 MW yaitu 31,97\% sedangkan efisiensi terendah diperoleh pada kondisi beban 64,04\% yaitu 27,91\%.

\section{KESIMPULAN}

Berdasarkan hasil dan pembahasan mengenai analisis pengaruh perubahan beban generator terhadap efsiensi kinerja PLTU bosowa energi jeneponto unit 2, dapat disimpulkan beberapa hal, sebagai berikut:

a. Dengan menggunakan poin 1, 2, dst. Berdasarkan dari hasil analisa dan pembahasan, maka pengaruh beban generator terhadap efisiensi kinerja PLTU yaitu berpengaruh, Efisiensi tertinggi terdapat pada tanggal 20 Mei 2018 pada pukul 18.00 dengan beban 90,00 MW yaitu 55,68\% dan efisiensi terendah terdapat pada tanggal 12 Mei 2018 pada pukul 03.00 dengan beban 64,98 MW yaitu 22,69\%.

b. Daya input boiler tertinggi berdasarkan hasil analisa terdapat pada tanggal 3 Mei pada pukul 20.00 yaitu 356,61 MW, serta daya input boiler terendah berdasarkan hasil analisa terdapat pada tanggal 15 Mei 2018 pada pukul 07.00 yaitu 128,14 MW.

\section{DAFTAR PUSTAKA}

[1] Abbas, Hammada, et al. "Analisa Pembangkit Tenaga Listrik Dengan Tenaga Uap Di Pltu." ILTEK: Jurnal Teknologi 14.01 (2019): 2024-2028.

[2] Trisnanto Munandar. Analisa Kinerja Generator Turbin Gas Terhadap Perubahan Beban Pada PT Indonesia Power Unit Pembangkit Semarang. Tugas Akhir, Jurusan Teknik Elektro Fakultas Teknik Universitas Semarang.2017.

[3] Choiri, Al, Emir Sabilillah, dan S. T. Umar. Analisis Pengaruh Pembebanan terhadap Efisiensi Transformator 20kV/150kV di PLTU Cilacap Unit 1\&2 2x300 MW PT. Sumber Segara Primadaya Cilacap. Diss. Universitas Muhammadiyah Surakarta, 2018.

[4] Purnomo, Joko, dan Mohammad Effendy. "Analisa Pengaruh Load Capacity Pembangkit Listrik Tenaga Uap Tanjung Awar-Awar 350 MW Terhadap Efisiensi Turbin Generator QFSN-350-2 Unit 1." Jurnal Pendidikan Teknik Mesin 7.3 (2018).

[5] Dwi Cahyadi, Hermawan. "Analisa Perhitungan Efisiensi Turbine Generator Qfsn-300-2-20b Unit 10 Dan 20 Pt. PJB UBJOM PLTU Rembang." (2015).

[6] Kurniawan, Hanzen Yauri, Hardi Gunawan, dan Benny Maluegha. "Kajian Efisiensi Termal Dari Boiler Di Pembangkit Listrik Tenaga Uap Amurang Unit 1." Jurnal Online Poros Teknik Mesin UNSRAT 4.2 (2015).

[7] Mohamad, Asep, dan Rachmat Subagyo. "Analisis Kinerja Boiler Pembangkit Listrik Tenaga Uap Asam Asam Unit II-Kalimantan Selatan." JTAM Rotary 2.1 (2020): 109-122.

[8] Muharrir, Muharrir, dan Ibnu Hajar. "Analisis Pengaruh Beban Terhadap Efisiensi Generator Unit 2 PLTP PT. Indonesia Power UPJP Kamojang." Kilat 8.2 (2019): 93-102.

[9] Jaelani, Dian, dan Sony Sukmara. "Analisa Efesiensi Ketel Uap Pada Unit 2 Pltu 2 Banten Kapasitas 300 Mw." Jurnal Konversi Energi dan Manufaktur UNJ 4.1 (2017): 25-32.

[10] Hermawan, Kholiq, dan Bagus Dwi Nurtanto. "Evaluasi Kinerja Boiler Unit 2 PLTU 2 BantenLabuan Menggunakan Metode Langsung Dan Tidak Langsung." Jurnal Teknik Energi 1.2 (2011): 84-89. 